\title{
Environmental, social, governance (ESG), and financial performance of European banks
}

\author{
Oana Marina Bătae ${ }^{a}$, Voicu Dan Dragomir ${ }^{\mathrm{a}}$ and Liliana Feleagă ${ }^{\mathrm{a}}$ \\ ${ }^{a}$ Bucharest University of Economic Studies, Romania
}

\begin{abstract}
Research Question: How do ESG and financial performance indicators vary according to different classifications of European banks?

Motivation: Banks' ESG performance and its relationship with corporate financial performance represents a field of continuous interest for researchers and practitioners. The results of previous studies are still mixed, either positive, negative, or even neutral.

What's new? The novelty of this paper is represented by the statistical comparison of variables that measure the ESG and financial performance of European banks based on three classifications that we propose (i.e. the geographical regions of Europe, functional currency, and cluster analysis on GDP and population of European countries, respectively). To the best of our knowledge, there are no studies applied to the banking sector, analyzing the selected variables between groups of banks according to the aforementioned classifications.

So what? We contribute to the field by extending Thomson Reuters' grouping of banks (Emerging and Developed Europe) with three more classifications. The comparison of ESG and financial performance data contributes to practice by highlighting which parts of Europe contain the banks with the highest and respectively the lowest values of ESG and financial performance, controversies, and audit fees. Therefore, the results will help investors, policymakers, regulatory bodies, bank managers, and auditors to acknowledge the significant differences within Europe and adopt appropriate measures that could improve the financial and sustainability performance of banks.

Data: We collect data from Thomson Reuters Eikon, World Bank statistics, and EuroVoc for 108 European banks (81 from Developed Europe and 27 for Emerging Europe) for 2018 , the most recent year on which all information is available.

Tools: We conduct a cluster analysis on the macroeconomic variables of the study: the GDP per capita and the population. We used group tests and the ANOVA test as methods in analyzing the results.
\end{abstract}

1 Corresponding author: Oana Marina Batae, The Bucharest University of Economic Studies, Faculty of Accounting and Management Information Systems, Ph.D. Candidate, 6 Piața Romană, 1st District, Bucharest, 010374, Romania, email address: oana.marinabatae@gmail.com. 
Findings and Contribution: We contribute with a quantitative study that fills the gap in the literature regarding significant differences that are obtained in ESG and financial performance of banks classified as Developed Europe versus Emerging Europe; Eurozone versus non-Euro countries; Western, CEE, Northern, and Southern banks; small GDP large population and large GDP - small population clusters. Our methodology will improve future research in adopting better and more transparent classifications of companies analyzed at an international level.

Keywords: Banking sector; ESG performance; Corporate social responsibility; Environmental performance; Corporate governance; Emerging Europe; Developed Europe

JEL codes: F64; G21; G34; M14; O16

\section{Introduction}

Banks play an important role in the financial stability of the global economy. As Scholtens and van't Klooster (2019) mentioned, banks are crucial for economic development, bearing a great responsibility across communities. Past banking scandals intensified the need for good corporate governance. Banks should focus on environmental protection, social involvement, and corporate governance (ESG) on a strategic level. For example, financing environmental projects should be included in the banks' risk strategy. Executives need to pay more attention to local communities, product quality, and workforce improvement as part of corporate social responsibility. Above all, implementing better governance structures will decrease business risk and create shareholder wealth.

Establishing corporate values represents an important process through which business leaders can communicate their vision to all employees and set the direction and strategy (Ehrenhard \& Fiorito, 2018). Banks that are considered too big to fail, also called "systemic" banks, have had their reputation affected by different scandals even if they had a functioning social responsibility system (Venturelli et al., 2018). However, the scandals and controversies linked to the role of banks in the financial crisis of 2008 have revealed failures in different corporate social dimensions and governance mechanisms (Esteban-Sanchez et al., 2017).

Banks are expected to play a dual role in relation to the sustainability of the financial sector. The internal role is related to the activities carried out in the normal course of business, while the external role refers to the inclusion of different ESG risks in their lending, financing, and investing decisions (Buallay et al., 2020). Directly or indirectly, corporate social responsibility (CSR) activities contribute to the sustainability of society while promoting competitiveness (Siueia et al., 2019). Friede et al. (2015) found that the business case for investing in ESG is empirically sound, on a meta-analysis conducted on more than 2000 studies. 
Still, further work is needed to better understand the processes behind ESG performance within the strategy of a company (Huang, 2019).

Considering that previous studies have mixed results on the association between ESG performance and financial performance, we highlight the fact that further work is still needed to better understand these relationships. To the best of our knowledge, there are no studies that specifically analyze these variables based on different classifications of the European banking sector.

Thus, we close the research gap through our contribution that is focused on analyzing the variables that measure ESG performance (environment, social, and governance), in addition to the financial performance of banks. We use several classifications related to the countries in which banks are headquartered. We considered the main classification from Reuters: Developed versus Emerging Europe. However, the criterion applied by Reuters is not described in the official methodology, thus being unclear. We propose three other classifications. The first classification is based on four geographical regions: Western, Southern, Northern, and CEE. The second classification is based on the functional currency of the respective countries: Eurozone and non-Euro countries. The third classification is based on a cluster analysis that produces two groups of European countries: small $G D P$ - large population and large GDP - small population.

We contribute to practice by highlighting the significant differences between different parts of Europe. These results may be used in assessing the actions implemented by European banks and identifying new opportunities to achieve greater levels of ESG and financial performance. Therefore, the results of this study are relevant to policymakers, regulatory bodies, banking managers, auditors, and investors.

We contribute to theory by proposing three more classifications of banks within Europe, extending the first classification found in Thomson Reuters, and offering further insights on ESG and financial performance, in line with previous studies.

Our research is structured as follows. The literature review serves for developing the hypotheses, while the sample, data sources, variables, and related definitions are detailed in the methodology section. The results of independent group tests are followed by the implications and conclusions of the study in the final part of the paper.

\section{Literature review}

The environmental, social, and governance practices are significant to all stakeholders within the banking sector. Good social and governance performance 
has a significant role in reducing financial risk and reinforcing the banks' commitment to good governance and environmental practices (Chollet \& Sandwidi, 2018). If the risk is low, financial uncertainty decreases, which leads to improving CSR involvement. Financial performance plays a significant role in the long-term decisions of management, as banks that report high levels of profitability do not worry about their near-term survival and can support CSR activities.

Nizam et al. (2019) mentioned that establishing ESG policies is a process that incurs costs for setting the ESG framework, due diligence, and current disclosure policies. Building up a strong ESG performance is expected to generate costs that shall be compensated by revenue stability, lower business risks, positive performance effects, and significant added value (Buallay, 2019a).

Previous studies in the literature have analyzed ESG performance and corporate scandals. A study by Buallay et al. (2020) on 882 banks from both developed and developing countries after the financial crisis of 2008, found that ESG performance has had a significant role in improving both accounting and market-based performance of banks located in developing countries. These results provide support for the value creation theory linked to non-financial indicators of corporate governance quality, risk management, and environmental and social performance.

The results of Shakil et al. (2019) on 93 banks from emerging markets showed a positive association between the banks' environmental/social performance and their financial performance. Moreover, Buallay et al. (2020) found that some developing countries are on the way of becoming a substantial contributor to global sustainability. In another study, Szegedi et al. (2020) mentioned that Pakistan, an emerging country, made an effort to develop its financial culture, adopting CSR practices. These practices were also analyzed in Turkey, an emerging country, by Akdogan et al. (2020). The results showed that social structure and economic development level represent key drivers in understanding CSR.

Ehrenhard and Fiorito (2018) analyzed the ethical values of the 25 largest European banks following the financial crisis. Integrity and customer focus were the most common values, and 15 banks were involved in different corporate scandals. Corporate controversies implied the facilitation of money laundering, dark pool activities, unauthorized trades, tax evasion, manipulation of both Libor and Euribor interbank interest rates, and the facilitation of different transactions with either individuals or companies from sanctioned countries. On the other hand, their results showed that banks with inclusive social principles such as solidarity, equality, and respect did not face any major scandal.

Different authors studied ESG performance at a disaggregated level. Buallay et al. (2019a) found that stakeholders of banks in the European Union take into consideration environmental practices when deciding on future investments, and 
the results show that this has brought wealth to the banking sector. Jo et al. (2015) asserted that customers in Europe also react more positively to environmental management. Thus, a greater and more significant effect is observed in the case of European banks compared to other regions, such as the Asia Pacific. Although it is true that the banking sector does not generate severe issues concerning environmental pollution, Miralles-Quirós et al. (2019) found that European banks are seeking to achieve savings on electricity, water, and use of paper.

According to the legitimacy theory, the rights of the public must be considered by companies, in addition to shareholder rights. Thus, several authors (Buallay, 2019b; Forcadell \& Aracil, 2017) have found that ESG involvement can strengthen a bank's legitimacy by demonstrating that profitability goes together with meeting the needs and expectations of stakeholders. However, CSR activities are sometimes controversial because of the high costs incurred in the process (Shen et al., 2016).

Social responsibility is a mechanism that has a significant contribution to restoring the banks' tarnished reputation after the economic crisis from 2008 (Buallay, Fadel, Alajmi et al., 2020; Forcadell \& Aracil, 2017). Instead of unidirectional communication and traditional legitimization strategies, banks need to disclose sufficient information regarding the effective involvement with stakeholders. Thus, Venturelli et al. (2018) found that stakeholder engagement represents a key strategic process, and a good indicator proving the commitment of banks to corporate social responsibility. Additionally, by satisfying the needs of stakeholders, companies may increase their profitability and improve their reputation (Buallay, Fadel, Alajmi et al., 2020).

Sustainability reporting is focused on creating future value (Buallay, 2019a), but CSR actions without proper disclosure would have little or no contribution to the banks' financial performance (Oyewumi et al., 2018). CSR disclosure plays a significant role in a company's debt placement decisions (Tan et al., 2020), and the intensity of CSR disclosure is associated with more persistent above-industrymedian gross and operating margins (Cannon et al., 2020). In a study performed on the Ghanaian banking sector, corporate social responsibility practices are found to be a strategic tool that may contribute to financial performance (Ofori et al., 2014). Conversely, Esteban-Sanchez et al. (2017) asserted that a strategic approach to CSR is not always implemented by banks. Relations with employees have a positive impact on financial performance, while community involvement and product responsibility are negatively associated with financial performance.

A country's system of corporate governance is able to improve earnings quality by increasing the supervision of companies and mitigating earnings management (Zehri \& Zgarni, 2020). Esteban-Sanchez et al. (2017) report a positive association between governance quality and financial performance. Also, disclosure of 
corporate governance is important within the banking sector. Better levels of governance disclosure are found by Buallay (2019b) within banks located in countries with high GDP. Such disclosures are costly items to prepare, as observed by Johansen and Plenborg (2013).

According to the agency theory, the alignment between the interests of managers and shareholders represents a mechanism of strong corporate governance, enhancing the company's value. Grove et al. (2011) applied this theory to the banking sector, expecting differences between financial institutions and other industrial companies, due to the regulatory environment specific to US banks. The results suggest there is a need for an extended version of agency theory that would better describe the banking sector. Consequently, agency conflicts might arise in different situations and can be reduced while building trust in relationships with stakeholders. Esteban-Sanchez et al. (2017) also rely on stakeholder theory to explain the accountability of banks not only to the shareholders but also to a wider audience.

Therefore, considering the significance of ESG performance in the literature, together with the four classifications of our research (i.e. Developed Europe versus Emerging Europe; Eurozone versus non-Euro countries; Western, CEE, Northern and Southern banks; small GDP - large population and large GDP - small population clusters), our first hypothesis is:

H1. There are significant differences in ESG performance between banks classified according to the four criteria in our study.

Various accounting indicators related to profitability, liquidity, or financial stability of companies are significant and regularly used by debtholders, as observed by Trpeska et al. (2017) in a study performed on banks in Macedonia. Several studies analyzed the relationship between ESG performance and different variables that measure banks' financial performance, such as size, liquidity, or capital adequacy. In most cases, size is measured as the logarithm of total assets or the number of employees. Financial performance can be influenced by either internal or external factors. An example of an external factor would be political interference, as observed by Samiul et al. (2019).

Beccalli et al. (2015) analyzed 103 European listed banks for the period 20002011. Total assets represent a major indicator of economies of scale within the banking system. Extremely large banks are also "too big to fail" and are of primary interest when analyzing economies of scale. The costs of ESG disclosure can be reduced in the case of larger banks because they also have economies of scale in the governance process (Nizam et al., 2019). 
Buallay et al. (2020) observed that large banks are monitored more closely and are under greater pressure. Such banks can obtain a better financial performance, as they are more efficient and have more resources, including the possibility to recruit skilled managers (Buallay, 2019a). Also, Platonova et al. (2018) linked ESG performance to financial performance and found that the effective use of resources is a result of social responsibility in Islamic banks.

The liquidity ratio represents another determinant of economies of scale. A higher ratio leads to lower liquidity risk, thus to greater economies of scale, as observed by Beccalli et al. (2015). In the same study on European banks, the authors highlighted the importance of capital strength, mentioning that tougher capital requirements lead to a decrease in costs, especially in the case of larger banks.

Also, capital adequacy represents a driver of a bank's responsibility that signals financial health (Gonenc \& Scholtens, 2019). Moreover, the findings of Pinto and Picoto (2018) show that the capital adequacy of European banks was managed through loan loss provisions after the financial crisis of 2008. These losses have a significant impact on the asset quality of the banking sector, thus on financial performance.

In line with the results of previous studies on the significance and implications of financial performance, our second hypothesis is:

H2. There are significant differences in financial performance between banks classified according to the four criteria in our study.

The starting point of our research is represented by the classification of countries in Developed versus Emerging Europe, according to Reuters. Afterward, we propose three different classifications that, in our opinion, are more transparent.

Ferri et al. (2015) published a similar study. The authors started from the ownership classification as given by Bankscope, then revised it after carefully reviewing all the available data. The authors created two new ownership classes: commercial or profit-maximizing banks ("shareholder banks"), and cooperative and savings banks ("stakeholder banks"). The results showed that shareholder banks were profitable before the crisis, while stakeholder banks had a better loan quality before and after the crisis.

To the best of our knowledge, there are no studies that address ESG, financial performance, and their related indicators, by using the classifications that we propose to be applied to the European banking sector. Thus, this study fills the gap in the literature regarding significant differences between Developed Europe versus Emerging Europe, Eurozone versus non-Euro countries; Western, CEE, Northern 
and Southern banks; and small GDP - large population versus large GDP - small population countries. Moreover, our study includes results on controversies and audit fees, areas of interest for different stakeholders.

\section{Methodology}

\subsection{Sample and data sources}

The population includes banks with headquarters in countries located in Europe. The main sources of data are Thomson Reuters, World Bank statistics, and EuroVoc - maintained by the Publication Office of the European Union. In the process of collecting data, we identified the countries located in Europe for which ESG data exists in Thomson Reuters. To obtain a comprehensive list of countries to be further analyzed, we extracted an overview of ESG scores for Emerging Europe and Developed Europe.

Secondly, we performed a cross-check to determine a complete and accurate population. We did not find two countries (Cyprus and Malta) in either Emerging or Developed Europe categories managed by Reuters. We compared the GDP of these countries with the GDP of others, such as the Czech Republic. Also, we observed that Cyprus has the second-lowest population in Europe. Therefore, we included these countries in Emerging Europe. Thomson Reuters considered three other countries to be part of Emerging Europe: Azerbaijan, Georgia, and Turkey. As a result of this phase, Emerging Europe includes 27 countries and Developed Europe includes 25 countries.

Thirdly, we extracted ESG scores for 2018 for 52 countries and we obtained the following results: Developed Europe includes a total of 234 banks, out of which 150 had no ESG data available and 84 banks qualified for further analysis; Emerging Europe includes a total of 169 banks, out of which 141 banks had no ESG data available and 28 banks qualified for further analysis. We further analyzed the qualifying population of 112 banks and we excluded four banks from the sample (two banks had no ESG data available for 2018 and two other banks are considered outliers because of the values registered by ESG combined, less than 10). Finally, the research baseline includes a total of 108 banks (81 from Developed Europe and 27 from Emerging Europe) and we considered the selection criterion to be represented by the availability of ESG combined score for 2018 .

The Refinitiv methodology does not contain Thomson Reuters' criteria for differentiating between Developed Europe and Emerging Europe. The authors have written to Reuters to ask for further clarification regarding the criterion for this taxonomy. As of the date of paper submission, Reuters has not provided the requested information. 
The sample per each country is included in Table 1 .

Table 1. European countries belonging to the main categories of the study

\begin{tabular}{lcllll}
\hline Country & Count & Reuters & Geography & Eurozone & $\begin{array}{l}\text { Wealth- } \\
\text { Population }\end{array}$ \\
\hline Austria & 3 & Developed & Western & Euro & $\uparrow$ GDPpc $\downarrow$ Pop \\
Belgium & 1 & Developed & Western & Euro & $\uparrow$ GDPpc $\downarrow$ Pop \\
Cyprus & 1 & Emerging & Southern & Euro & $\downarrow$ GDPpc $\uparrow$ Pop \\
The Czech Rep. & 2 & Emerging & CEE & Non-euro & $\downarrow$ GDPpc $\uparrow$ Pop \\
Denmark & 4 & Developed & Northern & Non-euro & $\uparrow$ GDPpc $\downarrow$ Pop \\
Finland & 2 & Developed & Northern & Euro & $\uparrow$ GDPpc $\downarrow$ Pop \\
France & 3 & Developed & Western & Euro & $\downarrow$ GDPpc $\uparrow$ Pop \\
Georgia & 2 & Emerging & CEE & Non-euro & $\downarrow$ GDPpc $\uparrow$ Pop \\
Germany & 5 & Developed & Western & Euro & $\downarrow$ GDPpc $\uparrow$ Pop \\
Greece & 4 & Developed & Southern & Euro & $\downarrow$ GDPpc $\uparrow$ Pop \\
Hungary & 1 & Emerging & CEE & Non-euro & $\downarrow$ GDPpc $\uparrow$ Pop \\
Ireland & 3 & Developed & Western & Euro & $\uparrow$ GDPpc $\downarrow$ Pop \\
Italy & 15 & Developed & Southern & Euro & $\downarrow$ GDPpc $\uparrow$ Pop \\
Liechtenstein & 1 & Developed & Western & Non-euro & $\uparrow$ GDPpc $\downarrow$ Pop \\
The Netherlands & 2 & Developed & Western & Non-euro & $\uparrow$ GDPpc $\downarrow$ Pop \\
Norway & 7 & Developed & Northern & Non-euro & $\uparrow$ GDPpc $\downarrow$ Pop \\
Poland & 10 & Emerging & CEE & Non-euro & $\downarrow$ GDPpc $\uparrow$ Pop \\
Portugal & 1 & Developed & Southern & Euro & $\downarrow$ GDPpc $\uparrow P o p$ \\
Romania & 2 & Emerging & CEE & Non-euro & $\downarrow$ GDPpc $\uparrow$ Pop \\
Russia & 4 & Emerging & CEE & Non-euro & $\downarrow$ GDPpc $\uparrow$ Pop \\
Spain & 8 & Developed & Southern & Euro & $\downarrow$ GDPpc $\uparrow P o p$ \\
Sweden & 4 & Developed & Northern & Non-euro & $\uparrow$ GDPpc $\downarrow$ Pop \\
Switzerland & 6 & Developed & Western & Non-euro & $\uparrow$ GDPpc $\downarrow$ Pop \\
Turkey & 8 & Emerging & Southern & Non-euro & $\downarrow$ GDPpc $\uparrow$ Pop \\
United Kingdom & 9 & Developed & Western & Non-euro & $\downarrow$ GDPpc $\uparrow P o p$ \\
\hline
\end{tabular}

We used Thomson Reuters as a source of financial data and ESG scores in the current study, in line with previous studies that analyzed the banking sector (Chollet \& Sandwidi, 2018; Dorfleitner et al., 2015; Gonenc \& Scholtens, 2019; Scholtens \& van't Klooster, 2019; Shakil et al., 2019).

\subsection{Analyzed variables and their definitions}

We collected ESG data from Thomson Reuters ESG scores which replaced and enhanced Asset4, the specialized ESG database utilized in the past. We used the most up to date framework from Thomson Reuters to collect the following variables: ESG_combined; Environment; Social; Governance; Controversies. These are defined in accordance with the ESG scores methodology published in April 2020 by Refinitiv. 
ESG combined score (ESG_combined) provides a comprehensive scoring of a bank's ESG performance, taking into account the ESG pillars and being discounted by the ESG controversies which are captured from global media sources. This was used in previous banking studies (Buallay, 2019b, 2019a; Buallay, Fadel, Al-Ajmi, et al., 2020; Buallay, Fadel, Alajmi, et al., 2020). We analyzed the three dimensions of ESG performance, these being: the environmental score (Environment), social score (Social), and governance score (Governance).

The environmental pillar score (Environment) is based on three scores: Resource use which reflects the capacity of a company to reduce the use of energy, water, materials and to find complementary solutions that are more eco-efficient; Emissions reduction which measures the effectiveness and commitment of a company in reducing the environmental emissions that are part of operational processes; and Innovation that reflects the capacity of a company to reduce the environmental costs through new technologies or eco-designed products.

The social pillar score (Social) takes into account four category scores: the Workforce score which measures the effectiveness of a company in providing a healthy and safe workplace, maintaining job satisfaction along with equal opportunities for its employees; Human rights that refer to the company's compliance to fundamental human rights conventions; the Community score which shows the company's commitment in respecting business ethics and public health; and Product responsibility that reflects the capacity of a company to produce quality goods and provide qualitative services.

The governance pillar score (Governance) combines three dimensions: the Management score shows the effectiveness towards applying best practices of corporate governance; the Shareholders score highlights the equal treatment of shareholders, including anti-takeover defenses; and the CSR strategy score reflects the practices of a specific company to properly communicate the integration of CSR initiatives in its daily activities.

The ESG controversies score (Controversies) is computed by Thomson Reuters based on different events that are presented in the media, such as lawsuits, fines, or ongoing legislation disputes. Still, this score has a market cap bias, as larger companies attract more media attention than smaller ones, and includes a list of 23 controversies defined by Thomson Reuters, such as anti-competition, business ethics, intellectual property, public health, tax fraud, human rights, management compensation, customer health and safety, privacy, product access, responsible marketing, responsible research and development costs, environmental, accounting, insider dealings, shareholder rights, diversity and opportunity, employee health and safety, wages or working condition, and strikes. In this research we recomputed the ESG controversies score by using the following: 


\section{Controversies $=100-$ Reuters controversies score}

A higher score for Controversies means that the bank has been involved in more public controversies, while the Reuters controversies score awards 100 points for no recorded controversies.

The variables that measure the financial performance, including others such as audit fees and GDP per capita, are defined in Table 2, in line with previous literature.

Table 2. Measurements of financial performance and other variables

\begin{tabular}{|c|c|c|c|}
\hline $\begin{array}{l}\text { Variable } \\
\text { (Abbreviation) }\end{array}$ & Definition & Source & Reference \\
\hline $\begin{array}{l}\text { Return on assets } \\
\left(\mathrm{ROA}^{*}\right)\end{array}$ & $\begin{array}{l}\text { Measures the profitability of total } \\
\text { assets and is calculated as net } \\
\text { income after taxes divided by total } \\
\text { assets. }\end{array}$ & TRC & $\begin{array}{l}\text { (Ahmed et al., 2019; } \\
\text { Ngoc, 2018) }\end{array}$ \\
\hline $\begin{array}{l}\text { Return on equity } \\
\left(\mathrm{ROE}^{*}\right)\end{array}$ & $\begin{array}{l}\text { Measures the profitability of the } \\
\text { invested capital from an } \\
\text { accounting perspective and } \\
\text { represents the ratio of net income } \\
\text { after taxes, divided by total equity. }\end{array}$ & $\mathrm{TRC}$ & $\begin{array}{l}\text { (Buallay, 2019b, } \\
\text { 2019a; Buallay, Fadel, } \\
\text { Al-Ajmi, et al., 2020; } \\
\text { Buallay, Fadel, Alajmi, } \\
\text { et al., 2020) }\end{array}$ \\
\hline $\begin{array}{l}\text { Total assets } \\
\text { (Total_assets) }\end{array}$ & $\begin{array}{l}\text { Represents a measure of the size } \\
\text { of banks, in terms of total assets. }\end{array}$ & TR & $\begin{array}{l}\text { (Jo et al., 2015; Lee et } \\
\text { al., 2014; Nizam et al., } \\
\text { 2019) }\end{array}$ \\
\hline $\begin{array}{l}\text { Employees } \\
\text { (Employees) }\end{array}$ & $\begin{array}{l}\text { Is a measure of the size of banks, } \\
\text { in terms of the total number of } \\
\text { employees. }\end{array}$ & TR & (Gangi et al., 2018) \\
\hline Leverage (Lev*) & $\begin{array}{l}\text { Is computed as the ratio of total } \\
\text { liabilities to total equity. This } \\
\text { financial indicator refers to a } \\
\text { bank's investment strategy of } \\
\text { using borrowed capital to create } \\
\text { value for shareholders. }\end{array}$ & TRC & $\begin{array}{l}\text { (Esteban-Sanchez et } \\
\text { al., 2017; Gangi et al., } \\
\text { 2018) }\end{array}$ \\
\hline $\begin{array}{l}\text { Capital } \\
\text { adequacy ratio } \\
(\text { CAPADQ*) }\end{array}$ & $\begin{array}{l}\text { Shows the extent to which a bank } \\
\text { can absorb losses using different } \\
\text { specific capital components, being } \\
\text { the most significant measure of } \\
\text { compliance with capital } \\
\text { requirements imposed by } \\
\text { regulators. Its formula is the ratio } \\
\text { of total owned funds to total risk- } \\
\text { weighted assets. }\end{array}$ & TR & $\begin{array}{l}\text { (Platonova et al., 2018; } \\
\text { Siueia } \text { et al., 2019; } \\
\text { Szegedi et al., 2020) }\end{array}$ \\
\hline
\end{tabular}




\begin{tabular}{|c|c|c|c|}
\hline $\begin{array}{l}\text { Variable } \\
\text { (Abbreviation) }\end{array}$ & Definition & Source & Reference \\
\hline $\begin{array}{l}\text { Audit fees } \\
\text { (Afees) }\end{array}$ & $\begin{array}{l}\text { Represent the fees required to } \\
\text { issue the audit reports in } \\
\text { accordance with the International } \\
\text { Auditing Standards on the } \\
\text { financial statements prepared in } \\
\text { accordance with IFRS. }\end{array}$ & TR & (Brooks et al., 2019) \\
\hline $\begin{array}{l}\text { GDP per capita } \\
\text { (GDPpc) }\end{array}$ & $\begin{array}{l}\text { Represents the (sum of gross } \\
\text { value added by all resident } \\
\text { producers in the economy plus } \\
\text { any product taxes and minus any } \\
\text { subsidies not included in the value } \\
\text { of the products) divided by the } \\
\text { midyear population. }\end{array}$ & WB & $\begin{array}{l}\text { (Gangi et al., 2018; } \\
\text { Shen } \text { et al., 2016) }\end{array}$ \\
\hline \multicolumn{4}{|c|}{$\begin{array}{l}\text { Notes: The abbreviations used in the text indicate the data sources: } \mathrm{WB}=\text { World Bank, TR } \\
\text { = Thomson Reuters, TRC }=\text { Computed by the authors with data from Thomson Reuters. } \\
(*) \text { The explanations are in line with definitions provided by the European Banking } \\
\text { Authority (EBA) for bank-specific indicators, included in the EBA methodological guide } \\
\text { that was issued in a revised draft in March } 2019 \text {. }\end{array}$} \\
\hline
\end{tabular}

In this research, we used the following classifications: the Reuters classification of Developed and Emerging Europe (CatID_Reuters); the geographical classification, according to which countries are included either in Western Europe, Central and Eastern Europe (CEE), Southern Europe, or Northern Europe (RegionID); the classification of Eurozone and non-Euro countries (Eurozone); and the clusters according to the GPD per capita and country population.

We conducted a cluster analysis on the macroeconomic variables of the study: the GDP per capita $(G D P p c)$ and the population (Population). In terms of the software of choice, we used IBM SPSS Statistics version 26, and we selected TwoStep Cluster Analysis as a procedure. This uses Schwarz's Bayesian Criterion as a clustering criterion, and the distance measure is log-likelihood. The resulting two clusters have different sizes, and we have named them 'the small GDP per capitalarge population' cluster $(\downarrow G D P p c \uparrow P o p)(\mathrm{n}=75)$, and 'the large GDP per capita small population' cluster $(\uparrow G D P p c \downarrow P o p)(\mathrm{n}=33)$.

We used group tests and the ANOVA test as methods in analyzing the results. In the Discussion section, we focused on the comparison between the country classifications and implications for future research.

\section{Empirical results}

The main contribution of this research is represented by the significant differences obtained on different variables while proposing three new classifications of 
countries within Europe: geographical classification into Western, CEE, Southern and Northern Europe; Eurozone and non-EURO countries; and two WealthPopulation clusters $(\downarrow G D P p c \uparrow P o p$ and $\uparrow G D P p c \downarrow$ Pop $)$. The proposed classifications of countries are more transparent than the split between Emerging and Developed Europe performed by Thomson Reuters.

The environmental, social, and governance pillar scores, including ESG combined score, are highly correlated with each other (see Table 3). The return on assets is moderately correlated with ESG combined score and highly correlated with ROE, while leverage has a strong inverse correlation with ROA. The capital adequacy ratio is moderately correlated with ROA, ROE, and leverage, while audit fees are highly correlated only with controversies. These results suggest that larger banks have, on average, better scores on environmental, social, and governance aspects taken separately, but are also involved in more controversies. This leads to a lack of correlation between the ESG combined score and the size of European banks (expressed either in Total assets or the number of Employees). Also, Social performance has the highest correlation with ESG combined, which suggests that the factor analysis of ESG components would show more relevant aspects of how this score is composed.

Table 3. Correlations between the main variables of the study

\begin{tabular}{|c|c|c|c|c|c|c|}
\hline & Environ. & Social & Govern. & Controv. & Empl. & Tot assets \\
\hline$E S G \_c o m b$. & $0.522 * *$ & $0.718 * *$ & $0.546^{* *}$ & -0.100 & 0.099 & 0.032 \\
\hline Environ. & & $0.728 * *$ & $0.335^{* *}$ & $0.451 * *$ & $0.356 * *$ & $0.488 * *$ \\
\hline Social & & & $0.461 * *$ & $0.443 * *$ & $0.451 * *$ & $0.458 * *$ \\
\hline Govern. & & & & $0.392 * *$ & $0.337 * *$ & $0.426 * *$ \\
\hline Controv. & & & & & $0.513 * *$ & $0.658 * *$ \\
\hline \multirow[t]{2}{*}{ Empl. } & & & & & & $0.789 * *$ \\
\hline & Controv0 & $R O A$ & $R O E$ & $L E V$ & CAPADQ & Afees \\
\hline$E S G \_c o m b$. & -0.100 & $0.297 * *$ & $0.295 * *$ & $-0.242 *$ & 0.022 & 0.012 \\
\hline Controv. & & $-0.199 *$ & -0.001 & $0.326 * *$ & -0.013 & $0.573 * *$ \\
\hline$R O A$ & & & $0.868 * *$ & $-0.525 * *$ & $0.273^{* *}$ & -0.182 \\
\hline$R O E$ & & & & $-0.319 * *$ & $0.373 * *$ & -0.128 \\
\hline$L E V$ & & & & & $0.407 * *$ & 0.167 \\
\hline$C A P A D Q$ & & & & & & -0.019 \\
\hline $\begin{array}{l}\text { Notes. } * p \\
\mathrm{~N}=108, \mathrm{e}\end{array}$ & $\begin{array}{l}* * p<0 \\
\text { AFees }\end{array}$ & 1). & & & & \\
\hline
\end{tabular}

The results of the independent group tests presented in Table 4 show significant differences in governance, controversies, total assets, leverage, capital adequacy ratio, and audit fees, between Developed Europe and Emerging Europe. The governance pillar score (Governance) is significantly higher for banks in Developed Europe. However, the same group of banks has significantly more 
controversies, probably because these corporations are significantly larger in terms of total assets. This is explained by the fact that larger banks get more attention from the media, and thus the probability of finding controversies is higher.

Leverage $(L E V)$ is significantly higher for banks in Developed Europe than for entities in Emerging Europe, the same trend being registered for capital adequacy ratio $(C A P A D Q)$. Audit fees are significantly higher for banks located in Developed Europe, in line with total assets. Larger banks require more work by the independent auditors, as the scope of work is extended. For variables such as the ESG combined score (ESG_combined), environmental pillar score (Environment), social pillar score (Social), number of employees (Employees), return on assets $(R O A)$ and return on equity (ROE), there are no significant differences between Developed Europe and Emerging Europe.

Table 4. Independent group tests between banks in Developed Europe versus Emerging Europe

\begin{tabular}{|c|c|c|c|c|c|}
\hline \multirow[t]{2}{*}{ Variables } & \multicolumn{2}{|c|}{$\begin{array}{l}\text { Developed Europe } \\
(\mathrm{n}=78)\end{array}$} & \multicolumn{2}{|c|}{$\begin{array}{l}\text { Emerging Europe } \\
(\mathrm{n}=\mathbf{3 0})\end{array}$} & \multirow[t]{2}{*}{$t$-statistic } \\
\hline & M & SD & M & SD & \\
\hline ESG comb. & 49.66 & 13.95 & 51.74 & 18.70 & -0.55 \\
\hline Environment & 53.98 & 30.83 & 43.55 & 27.52 & 1.57 \\
\hline Social & 62.17 & 20.87 & 56.50 & 23.21 & 1.22 \\
\hline Governance & 60.77 & 21.70 & 50.96 & 21.19 & $2.11 *$ \\
\hline Controversies & 35.90 & 37.37 & 6.71 & 15.32 & $5.75 * *$ \\
\hline Employees & 29512 & 48538 & 26782 & 54280 & .25 \\
\hline Total_assets & 301419 & 487927 & 50615 & 73992 & $4.41 * *$ \\
\hline$R O A^{-}$ & 0.642 & 0.672 & 0.970 & 1.903 & -0.92 \\
\hline$R O E$ & 7.971 & 6.330 & 2.849 & 40.625 & .687 \\
\hline$L E V$ & 13.54 & 5.40 & 9.26 & 4.18 & $3.90 * *$ \\
\hline$C A P A D Q$ & 18.29 & 4.67 & 16.07 & 3.65 & $2.34^{*}$ \\
\hline AFees & 13.34 & 28.76 & .98 & .91 & $3.48 * *$ \\
\hline
\end{tabular}

Notes. Group differences are significant at $* p<0.05 ; * * p<0.01$.

For AFees, Developed Europe has 66 cases, and Emerging Europe has 15 cases.

The results of the ANOVA test are presented in Table 5. The ESG combined score of Southern banks is significantly higher than the score of Northern banks, but it is not statistically different from the scores of Western and CEE banks. The same applies to the Social pillar score, but Northern banks also have a significantly higher score than CEE banks. The governance pillar score (Governance) of Western banks is significantly higher than the score of Northern banks, without being statistically different from the scores of Southern and CEE banks. The Environmental pillar score is statistically similar for the four groups of countries.

The ESG controversies score (Controversies) is significantly higher for Western banks compared to CEE banks, like the Governance pillar score. This is because 
Western banks are also significantly larger than Northern banks and CEE banks. Also, Western banks have significantly higher leverage than CEE banks, which is also the case for audit fees. Western and Northern banks are similar in terms of capital adequacy, but they have significantly higher ratios than Southern and CEE banks. However, there is no significant difference in terms of ROA for the four groups, while the variance for ROE is too large for the test to determine any significant differences for the entire sample.

Table 5. Results of one-way ANOVA for geographical regions in Europe

\begin{tabular}{|c|c|c|c|c|c|}
\hline Variables & $\begin{array}{l}\text { Western } \\
M(S D) \\
\mathrm{N}=\mathbf{3 3}\end{array}$ & $\begin{array}{l}\text { Southern } \\
M(S D) \\
\mathbf{N}=\mathbf{3 7}\end{array}$ & $\begin{array}{l}\text { Northern } \\
M(S D) \\
\mathrm{N}=17\end{array}$ & $\begin{array}{l}\text { CEE } \\
M(S D) \\
\mathrm{N}=\mathbf{2 1}\end{array}$ & $\boldsymbol{F}$ \\
\hline ESG_comb. & $48.7(12.7)$ & $55.8(13.9)^{\mathrm{a}}$ & $43.4(13.7)^{b}$ & $48.3(19.9)$ & $3.145^{*}$ \\
\hline Environment & $52.9(35.1)$ & $54.8(28.8)$ & $57.7(29.4)$ & $35.7(26.6)$ & 2.184 \\
\hline Social & $62.7(22.3)$ & $68.5(17.3)^{a}$ & $51.5(19.3)^{b}$ & $50.7(23.8)^{b}$ & $4.690 * *$ \\
\hline Governance & $67.9(18.7)^{\mathrm{a}}$ & $56.5(22.8)$ & $48.3(19.7)^{b}$ & $53.1(22.2)$ & $4.088 * *$ \\
\hline Controversies & $42.9(39.9)^{\mathrm{a}}$ & $28.5(31.8)$ & $25.0(37.5)^{\mathrm{a}}$ & $4.9(14.7)^{b}$ & $5.672 * *$ \\
\hline Employees & $\begin{array}{r}42803 \\
(58376)^{\mathrm{a}}\end{array}$ & $\begin{array}{r}25769 \\
(40656)^{a}\end{array}$ & $\begin{array}{r}6780 \\
(8732)^{\mathrm{b}}\end{array}$ & $\begin{array}{r}29722 \\
(64099)\end{array}$ & 2.074 \\
\hline Total_assets & $\begin{array}{r}481582 \\
(633779)^{a}\end{array}$ & $\begin{array}{r}171094 \\
(297982)\end{array}$ & $\begin{array}{r}103954 \\
(172800)^{b}\end{array}$ & $\begin{array}{r}49486 \\
(87806)^{b}\end{array}$ & $6.590 * *$ \\
\hline$R O A$ & $0.59(0.60)$ & $0.63(0.71)$ & $1.08(0.74)$ & $0.87(2.24)$ & 0.877 \\
\hline$R O E$ & $7.44(5.11)^{a}$ & $7.35(7.66)^{a}$ & $11.94(3.9)^{b}$ & $-0.64(48.31)$ & 1.133 \\
\hline$L E V$ & $14.7(6.4)^{\mathrm{a}}$ & $11.9(4.3)$ & $12.2(4.8)$ & $9.6(4.8)^{b}$ & $4.314^{* *}$ \\
\hline$C A P A D Q$ & $19.39(5.8)^{\mathrm{a}}$ & $16(2.9)^{b}$ & $19.76(2.3)^{\mathrm{a}}$ & $16.24(4.3)^{b}$ & $5.904 * *$ \\
\hline Afees & $22.0(36.1)^{\mathrm{a}}$ & $8.5(21.5)$ & $1.1(1.4)^{b}$ & $0.8(0.5)^{b}$ & $3.555^{*}$ \\
\hline
\end{tabular}

Notes. The $F$ statistic is significant at $* p<0.05 ; * * p<0.01$

We use the Games Howell post hoc test for groups where homogeneity of variances is not assumed. Differing superscripts $\left({ }^{\mathrm{abc}} \mathrm{d}\right)$ indicate significant differences between the respective groups at $* p<0.05$

The results of independent group tests presented in Table 6 show that the social pillar scores (Social) and leverage (LEV) are significantly higher for banks that are part of the Eurozone compared to entities located in non-Euro countries. Conversely, return on assets $(R O A)$ is significantly higher for banks with headquarters located in Non-Euro countries compared to Eurozone.

Table 6. Independent group tests between banks in Eurozone versus non-Euro countries

\begin{tabular}{|c|c|c|c|c|c|}
\hline \multirow[t]{2}{*}{ Variables } & \multicolumn{2}{|l|}{$\begin{array}{l}\text { Eurozone } \\
(n=48)\end{array}$} & \multicolumn{2}{|l|}{$\begin{array}{l}\text { Non-Euro } \\
(\mathrm{n}=60)\end{array}$} & \multirow[t]{2}{*}{$t$-statistic } \\
\hline & $M$ & $S D$ & $M$ & $S D$ & \\
\hline$E S G \_c o m b$. & 53.09 & 13.98 & 47.97 & 16.12 & 1.738 \\
\hline Environment & 56.57 & 29.67 & 46.59 & 30.14 & 1.686 \\
\hline Social & 66.84 & 18.44 & 55.60 & 22.74 & $2.835 * *$ \\
\hline Governance & 59.94 & 21.98 & 56.53 & 21.93 & 0.800 \\
\hline
\end{tabular}




\begin{tabular}{|c|c|c|c|c|c|}
\hline \multirow[t]{2}{*}{ Variables } & \multicolumn{2}{|l|}{$\begin{array}{l}\text { Eurozone } \\
(n=48)\end{array}$} & \multicolumn{2}{|l|}{$\begin{array}{l}\text { Non-Euro } \\
(\mathrm{n}=60)\end{array}$} & \multirow[t]{2}{*}{$t$-statistic } \\
\hline & $M$ & $S D$ & $M$ & $S D$ & \\
\hline Controversies & 34.78 & 35.21 & 22.19 & 34.52 & 1.866 \\
\hline Employees & 33574 & 49164 & 24897 & 50657 & 0.896 \\
\hline Total_assets & 324110 & 487766 & 157864 & 366712 & 1.960 \\
\hline$R O A$ & 0.458 & 0.527 & 0.954 & 1.441 & $-2.469 *$ \\
\hline$R O E$ & 6.5485 & 6.543 & 6.5483 & 28.966 & 0 \\
\hline$L E V$ & 14.03 & 5.84 & 11.01 & 4.69 & $2.976 * *$ \\
\hline$C A P A D Q$ & 17.70 & 5.61 & 17.65 & 3.43 & 0.047 \\
\hline AFees & 11.93 & 21.93 & 10.23 & 30.17 & 0.289 \\
\hline
\end{tabular}

Notes. Group differences are significant at $* p<0.05 ; * * p<0.01$.

For AFees, Eurozone has 39 cases, and non-Euro countries have 42 cases.

Table 7 shows that the ESG combined score (ESG_combined) and the social pillar score (Social) are significantly higher in the case of banks located in countries part of small GDP per capita - large population cluster. The capital adequacy ratio $(C A P A D Q)$ is significantly lower in the same cluster, which also features significantly larger banks in terms of the number of employees.

Table 7. Independent group tests between banks in the two Wealth-Population clusters

\begin{tabular}{|c|c|c|c|c|c|}
\hline \multirow[t]{2}{*}{ Variables } & \multicolumn{2}{|c|}{$\begin{array}{l}\downarrow \text { GDPpc } \uparrow \text { Pop } \\
(N=75)\end{array}$} & \multicolumn{2}{|c|}{$\begin{array}{l}\uparrow \text { GDPpc } \downarrow \text { Pop } \\
(\mathbf{N}=\mathbf{3 3})\end{array}$} & \multirow[t]{2}{*}{$t$-statistic } \\
\hline & $M$ & $S D$ & $M$ & $S D$ & \\
\hline$E S G \_c o m b$. & 52.20 & 15.22 & 45.79 & 14.93 & $2.026^{*}$ \\
\hline Environment & 50.55 & 29.93 & 52.53 & 31.26 & -0.304 \\
\hline Social & 63.81 & 21.47 & 53.28 & 20.30 & $2.387^{*}$ \\
\hline Governance & 60.33 & 22.80 & 52.86 & 19.06 & 1.644 \\
\hline Controversies & 29.02 & 35.21 & 24.99 & 35.67 & 0.546 \\
\hline Employees & 35965 & 57614 & 12363 & 16408 & $3.260 * *$ \\
\hline Total_assets & 268666 & 493006 & 147853 & 218852 & 1.764 \\
\hline$R O A$ & 0.649 & 1.298 & 0.924 & 0.703 & -1.141 \\
\hline$R O E$ & 4.875 & 26.053 & 10.349 & 4.328 & -1.197 \\
\hline$L E V$ & 12.351 & 5.789 & 12.366 & 4.582 & -0.014 \\
\hline$C A P A D Q$ & 17.078 & 5.09 & 19.040 & 2.28 & $-2.116^{*}$ \\
\hline AFees & 14.16 & 31.72 & 5.48 & 10.21 & 1.812 \\
\hline
\end{tabular}

Notes. Group differences are significant at $* p<0.05 ; * * p<0.01$.

For AFees, $\downarrow$ GDPpc $\uparrow$ Pop has 52 cases, and the $\uparrow$ GDPpc $\downarrow$ Pop group has 29 cases.

\section{Discussions and conclusions}

Our research analyzes different ESG and financial variables for banks located in European countries according to four classifications. We started with the classification proposed by Thomson Reuters which does not include details in the methodology published on the official website. Therefore, we aim to observe what 
are the main differences between Developed and Emerging Europe and the other three proposed classifications.

In terms of the ESG combined score, there are no significant differences between Developed and Emerging Europe. We obtained the same results when analyzing ESG combined between Eurozone versus non-Euro countries. However, compared to the Reuters classification, banks in Southern European countries and the small $G D P$ - large population cluster have a significantly higher ESG combined score, which may also be correlated with the results on the Social pillar score.

We did not observe significant differences in the Environmental pillar score in Developed versus Emerging Europe. We do not obtain results that are statistically significant for the four geographical regions in Europe, respectively the Eurozone versus non-EURO, or the two Wealth-Population clusters. Thus, our results show the same trend as the one obtained when analyzing the classification of Thomson Reuters. This is in line with the study of Jo et al. (2015), considering that European customers react positively to environmental management and there is relative uniformity in this domain.

For the Social pillar score, there are no significant differences between Developed and Emerging Europe. However, the Social performance score of Southern banks is significantly higher than the score of Northern and CEE banks. Similarly, banks in Eurozone countries have significantly higher social scores than banks in nonEuro countries. Thus, differences arise are dependent on various factors, such as relations with employees, community involvement, or product responsibility.

The Governance pillar score and Controversies score are significantly higher in Developed Europe compared to Emerging Europe. We obtained significant differences based only on geographical criteria. The Governance pillar score and ESG controversies score for Western banks are significantly higher than the ones of Northern banks. This result brings more detail to the analysis of Developed versus Emerging Europe, as banks classified in Western, respectively Northern regions, are all part of Developed Europe according to Thomson Reuters collected data.

The total assets of banks in Developed Europe are significantly higher compared to banks in Emerging Europe, while the number of employees is also higher, but not significantly different. Also, the total assets of Western banks are significantly higher than Northern and CEE banks, while the number of employees of Western banks is higher, but not statistically significant. The same trend is found for the two size variables in the case of the Eurozone versus non-Euro countries, the differences being statistically not significant. However, the number of employees 
from the small GDP - large population cluster is significantly higher than the average number of bank employees in large GDP - small population countries.

The ROA of banks in Emerging Europe is higher, but not statistically different, compared to Developed Europe, while in the case of ROE the relationship is inverse. The highest ROA and ROE are observed, on average, in the case of Northern banks and, respectively, the large GDP - small population cluster. The ROA and ROE do not significantly differ when comparing Southern with Northern banks. The results of the independent group tests show no differences in the case of ROE when comparing Eurozone with non-Euro countries.

The leverage and capital adequacy of banks in Developed Europe are significantly higher than those of entities in Emerging Europe. We report higher leverage for Eurozone banks compared to non-Euro countries, but there is no difference in terms of capital adequacy for banks in these two groups. Differences arise when analyzing the geographical classification. The leverage of Western banks is significantly higher than the leverage of CEE banks, while Northern and Western banks have higher capital adequacy than Southern and CEE banks. Entities in Developed Europe and the large GDP - small population cluster have significantly higher capital adequacy than their peers. Thus, different parts of Europe encounter better financial health compared to others, in line with competitive advantages gained by some countries. A bank's financial stability represents a signal of accountability linked to ensuring an acceptable capital adequacy level (Gonenc and Scholtens, 2019). The acceptable level of the ratio, usually, is given by the regulator.

As expected, the audit fees are significantly higher for banks in Developed Europe. Similarly, the audit fees of Western banks are significantly higher than the audit fees or Northern and CEE banks. The Reuters classification includes Western, Northern, and some Southern banks in Developed Europe, but there is no significant difference between Western and Southern banks.

This study contributes to the literature by highlighting the differences between variables in the case of four classifications, thus addressing the research gap. The first classification is the one proposed by Thomson Reuters, analyzing ESG performance and related pillars, including the Controversies score, by comparing Developed Europe with Emerging Europe. Based on the methodology published by Thomson Reuters on its official website, it can be concluded that this classification lacks transparency, as it is not clear what is the criterion used to obtain this split. Thus, we analyze the variables by proposing three other classifications. The first one is based on four geographical regions: Western, Southern, Northern, and CEE. The second classification is based on the functional currency of countries in which the banks' headquarters are located: Eurozone and non-Euro countries. The third 
classification is based on a cluster analysis that produced two groups of European countries: small GDP - large population and large GDP - small population.

The evidence from this study may help banks in identifying where the highest values of ESG components, controversies, performance indicators, and audit fees are found. Also, banks and regulators could see more clearly which are the components where improvement or actions are still needed to reach and maintain higher ESG and financial performance, and thus higher value for the shareholders.

Future research may focus on the impact the new Coronavirus will have on the banking sector. ESG and financial performance are expected to change significantly due to the pandemic crisis. Moreover, the business plans and set of actions adopted by banks to face the Coronavirus will reshape workforce norms, organizational culture, digital skills, and regulatory requirements. Thus, new challenges arising from the Covid-19 crisis in different geographical regions of Europe may be subject to extensive investigations.

\section{Acknowledgement}

This work was co-financed from the European Social Fund through Operational Programme Human Capital 2014-2020, project number POCU/380/6/13/125015 "Development of entrepreneurial skills for doctoral students and postdoctoral researchers in the field of economic sciences".

\section{References}

Ahmed, S.P., Ahmed, S.U., Noor, M.F., Ahmed, Z. \& Karmaker, U. (2019) "The policy-led sustainability and financial performance linkage in the banking sector: Case of Bangladesh", Banks and Bank Systems, vol. 14 no. 4: 89-103

Akdogan, N., Selimoglu, S.K. \& Turkcan, M. (2020) "Sustainability accounting and corporate social responsibility in Turkey and in its region", Journal of Accounting and Management Information Systems, vol. 19 no. 1: 5-32

Beccalli, E., Anolli, M. \& Borello, G. (2015) "Are European banks too big? Evidence on economies of scale", Journal of Banking and Finance, vol. 58: 232-246

Brooks, L. Z., Gill, S. \& Wong-On-Wing, B. (2019) "Corporate social responsibility risk and auditor-client retention", International Journal of Auditing, vol. 23 no. 1: 95-111

Buallay, A. (2019a) "Is sustainability reporting (ESG) associated with performance? Evidence from the European banking sector", Management of Environmental Quality: An International Journal, vol. 30 no. 1: 98-115

Buallay, A. (2019b) "Sustainability reporting and firm's performance: Comparative study between manufacturing and banking sectors", International Journal of Productivity and Performance Management, vol. 69 no. 3: 431-445 
Buallay, A., Fadel, S.M., Al-Ajmi, J.Y. \& Saudagaran, S. (2020) "Sustainability reporting and performance of MENA banks: is there a trade-off?", Measuring Business Excellence, vol. 24 no. 2: 197-221

Buallay, A., Fadel, S.M., Alajmi, J. \& Saudagaran, S. (2020) "Sustainability reporting and bank performance after financial crisis", Competitiveness Review: An International Business Journal, in press

Cannon, J.N., Ling, Z., Wang, Q. \& Watanabe, O. V. (2020) "10-K disclosure of corporate social responsibility and firms' competitive advantages", European Accounting Review, vol. 29 no. 1: 85-113

Chollet, P. \& Sandwidi, B.W. (2018) "CSR engagement and financial risk: A virtuous circle? International evidence", Global Finance Journal, Elsevier Inc, vol. 38: 65-81

Dorfleitner, G., Halbritter, G. \& Nguyen, M. (2015) "Measuring the level and risk of corporate responsibility - An empirical comparison of different ESG rating approaches", Journal of Asset Management, vol. 16 no. 7: 450-466

Ehrenhard, M.L. \& Fiorito, T.L. (2018) "Corporate values of the 25 largest European banks: Exploring the ambiguous link with corporate scandals", Journal of Public Affairs, vol. 18 no. 1: e1700

Esteban-Sanchez, P., de la Cuesta-Gonzalez, M. \& Paredes-Gazquez, J.D. (2017) "Corporate social performance and its relation with corporate financial performance: International evidence in the banking industry", Journal of Cleaner Production, Elsevier B.V., vol. 162: 1102-1110

Ferri, G., Kalmi, P. \& Kerola, E. (2015) "Organizational structure and performance in European banks: A reassessment", Advances in the Economic Analysis of Participatory and Labor-Managed Firms, Vol. 16, pp. 109-141

Forcadell, F.J. \& Aracil, E. (2017) "European banks' reputation for corporate social responsibility", Corporate Social Responsibility and Environmental Management, vol. 24 no. 1: 1-14

Friede, G., Busch, T. \& Bassen, A. (2015) "ESG and financial performance: aggregated evidence from more than 2000 empirical studies", Journal of Sustainable Finance and Investment, vol. 5 no. 4: 210-233

Gangi, F., Mustilli, M., Varrone, N. \& Daniele, L.M. (2018) "Corporate social responsibility and banks' financial performance", International Business Research, vol. 11 no. 10: 42

Gonenc, H. \& Scholtens, B. (2019) "Responsibility and performance relationship in the banking industry", Sustainability (Switzerland), vol. 11 no. 12: 1-49

Grove, H., Patelli, L., Victoravich, L.M. \& Xu, P.T. (2011) "Corporate governance and performance in the wake of the financial crisis: Evidence from US commercial banks", Corporate Governance: An International Review, vol. 19 no. 5: 418-436

Huang, D.Z.X. (2019) "Environmental, social and governance (ESG) activity and firm performance: a review and consolidation", Accounting and Finance, acfi. 12569 
Jo, H., Kim, H. \& Park, K. (2015) "Corporate environmental responsibility and firm performance in the financial services sector", Journal of Business Ethics, vol. 131 no. $2: 257-284$

Johansen, T.R. \& Plenborg, T. (2013) "Prioritising disclosures in the annual report", Accounting and Business Research, vol. 43 no. 6: 605-635

Lee, C.C., Yang, S.J. \& Chang, C.H. (2014) "Non-interest income, profitability, and risk in banking industry: A cross-country analysis", North American Journal of Economics and Finance, vol. 27: 48-67

Miralles-Quirós, M.M., Miralles-Quirós, J.L. \& Hernández, J.R. (2019) “ESG performance and shareholder value creation in the banking industry: International differences", Sustainability (Switzerland), vol. 11 no. 5: 1404

Ngoc, N.B. (2018) "The effect of corporate social responsibility disclosure on financial performance: Evidence from credit institutions in Vietnam", Asian Social Science, vol. 14 no. 4: 109

Nizam, E., Ng, A., Dewandaru, G., Nagayev, R. \& Nkoba, M.A. (2019) "The impact of social and environmental sustainability on financial performance: A global analysis of the banking sector", Journal of Multinational Financial Management, Elsevier B.V., vol. 49: 35-53

Ofori, D.F., Nyuur, R.B. \& S-Darko, M.D. (2014) "Corporate social responsibility and financial performance: Fact or fiction? A look at Ghanaian banks", Acta Commercii, vol. 14 no. 1: 1-11

Oyewumi, O.R., Ogunmeru, O.A. \& Oboh, C.S. (2018) "Investment in corporate social responsibility, disclosure practices, and financial performance of banks in Nigeria", Future Business Journal, Elsevier B.V., vol. 4 no. 2: 195-205

Pinto, I. \& Ng Picoto, W. (2018) "Earnings and capital management in European banks - Combining a multivariate regression with a qualitative comparative analysis", Journal of Business Research, vol. 89: 258-264

Platonova, E., Asutay, M., Dixon, R. \& Mohammad, S. (2018) "The impact of corporate social responsibility disclosure on financial performance: Evidence from the GCC Islamic banking sector", Journal of Business Ethics, Springer Netherlands, vol. 151 no. 2: 451-471

Scholtens, B. \& van't Klooster, S. (2019) "Sustainability and bank risk", Palgrave Communications, Springer US, vol. 5 no. 1: 1-8

Shakil, M.H., Mahmood, N., Tasnia, M. \& Munim, Z.H. (2019) "Do environmental, social and governance performance affect the financial performance of banks? A cross-country study of emerging market banks", Management of Environmental Quality: An International Journal, vol. 30 no. 6: 1331-1344

Shen, C.H., Wu, M.W., Chen, T.H. \& Fang, H. (2016) "To engage or not to engage in corporate social responsibility: Empirical evidence from global banking sector”, Economic Modelling, Elsevier B.V., vol. 55: 207-225

Siueia, T.T., Wang, J. \& Deladem, T.G. (2019) "Corporate social responsibility and financial performance: A comparative study in the Sub-Saharan Africa banking sector", Journal of Cleaner Production, Elsevier Ltd, vol. 226: 658-668 
Szegedi, K., Khan, Y. \& Lentner, C. (2020) "Corporate social responsibility and financial performance: Evidence from Pakistani listed banks", Sustainability (Switzerland), vol. 12 no. 10: 1-19

Tan, W., Tsang, A., Wang, W. \& Zhang, W. (2020) "Corporate social responsibility (CSR) disclosure and the choice between bank debt and public debt", Accounting Horizons, vol. 34 no. 1: 151-173

Trpeska, M., Atanasovski, A. \& Bozinovska Lazarevska, Z. (2017) “The relevance of financial information and contents of the new audit report for lending decisions of commercial banks", Journal of Accounting and Management Information Systems, vol. 16 no. 4: 455-471

Venturelli, A., Cosma, S. \& Leopizzi, R. (2018) "Stakeholder engagement: An evaluation of european banks", Corporate Social Responsibility and Environmental Management, vol. 25 no. 4: 690-703

Zehri, F. \& Zgarni, I. (2020) "Internal and external corporate governance mechanisms and earnings management: an international perspective", Journal of Accounting and Management Information Systems, vol. 19 no. 1: 33-64 